\title{
Usklađenost tjelesne konstitucije i prehrane s obzirom na ayurvedske principe
}

\section{Compatibility of body constitutions (prakriti) and diet considering ayurvedic principles}

\author{
Maja Ćaćić*, Ana Vukelić, Zvonimir Šatalić \\ Prehrambeno-biotehnološki fakultet Sveučilišta u Zagrebu, Pierottijeva 6, 10000 Zagreb, Hrvatska \\ *Corresponding author: majacacic92@gmail.com
}

Sažetak

Ayurvedska medicina je priznata od strane Svjetske zdravstvene organizacije, a usporedba principa suvremene znanosti o prehrani i ayurvedskih principa pokazuje određene podudarnosti. Cilj ovog istraživanja je bio ispitati korelaciju prehrambenih navika i tjelesne konstitucije ispitanika prema principima ayurvede. Podaci o tjelesnoj konstituciji (prakriti) dobiveni su ispunjavanjem testa za doshe, dok su podaci o prehrani prikupljeni upitnikom o učestalosti konzumiranja te posebno razvijenim upitnikom za prehrambene navike. U istraživanju je sudjelovalo 210 odraslih ispitanika (38,6\% muškaraca, 61,4\% žena). Od ukupnog broja ispitanika, 131 (62,38\%) imaju uravnoteženu tjelesnu konstituciju, dok njih 79 (37, 62 \%) ima uneravnoteženu konstituciju. Za kapha tjelesnu konstituciju, rezultati su pokazali povezanost prehrambenih navika $i$ konstitucije. Kod uneravnoteženih tjelesnih konstitucija, povezanost je uočena samo kod pitta neravnoteže i njezinih prehrambenih navika.

Ključne riječi: ayurveda, dosha, prakriti,vikriti, holistički pristup

Abstract

Ayurvedic medicine is recognized by the World Health Organization, while comparing the principles of modern nutrition and ayurvedic principles shows some correlations. The aim of this study was examine the correlation between dietary habits and physical constitution of subjects according to the principles of ayurveda. Data on the body constitution (prakriti) were obtained by filling the dosha test, while dietary data were collected through a food frequency questionnaire and a specially developed questionnaire for nutrition habits. The study involved 210 adult subjects (38.6\% male, 61.4\% female). From the total number of respondents, 131 (62.38\%) had balanced body constitution, while 79 (37.62\%) had unbalanced constitution. For the kapha body constitution, the results showed the correlation between eating habits and constitution. With unbalanced body constitution, the association is only observed with the pitta imbalance and its eating habits.

Keywords: ayurveda, dosha, prakriti, vikriti, holistic approach

\section{Uvod}

Tradicionalna medicina se definira kao znanja, vještine i prakse holističke njege, priznate i prihvaćene u održavanju zdravlja i liječenja bolesti, a sva iskustva i vjerovanja prenose se generacijski (Choi, 2009). U tradicionalnu medicinu uvrštava se i ayurveda.

Ayurveda (san. ayur-život, veda-znanost) (Collins, 2011) se definira kao tradicionalna indijska medicina, gdje je prakticirana već više tisuća godina (Chaudhary i Singh, 2011), a danas se primjenjuje u cijelom svijetu (Petrušić, 2015). Priznata je od strane Svjetske zdravstvene organizacije (SZO) (Chaudhary i Singh, 2011). Njezin je glavni cilj ostvariti dobro stanje čovjeka prevencijom bolesti, poticanje zdravlja i dugovječnosti a potom i liječenje bolesti (Acharya, 2002). Ayurveda, kao i tradicionalna kineska medicina, naturopatija i homeopatija pripadaju cjelovitom medicinskom sustavu jer svaka od njih obuhvaća širok raspon tretmana i liječenja bolesti (Barnett i Shale, 2012). Za potrebe razumijevanja ayurvede potrebno je objasniti osnovne pojmove na kojima se temelji (tablica 1).

Tablica 1. Prikaz pojmova važnih za razumijevanje ayurvede Table 1. Terms important for understanding ayurveda

\begin{tabular}{|l|l|}
\hline Pojam & Definicija \\
\hline Dosha & $\begin{array}{l}\text { Tri osnovne energije; temelj fiziologije } \\
\text { tijela na kojem počivaju sve životne } \\
\text { funkcije }\end{array}$ \\
\hline $\begin{array}{l}\text { Prakriti } \\
\text { (konstitucijski tip) }\end{array}$ & $\begin{array}{l}\text { Konstitucijski tip, prirodno stanje uma i } \\
\text { tijela; postoji ih 7 }\end{array}$ \\
\hline Vikriti & $\begin{array}{l}\text { Trenutačno stanje tijela koje bi trebalo } \\
\text { odražavati prakriti što je više moguće }\end{array}$ \\
\hline
\end{tabular}


Ayurveda uči kako su sva živa bića i priroda izgrađeni od pet elemenata: eter (prostor u kojem se odvijaju pojave, ili struji zrak, akash), zrak (vayu), voda (jala), vatra (tejo), zemlja (prithvi) (Sharma i Clark, 1997). Moderna znanost podupire ovu teoriju o pet elemenata koji izgrađuju fizički svijet preko osnovnih formativnih čestica (elektroni, protoni i neutroni) kombiniranih u različitim omjerima izgrađujući atome, elemente i spojeve (Rastogi, 2010). Kombinacijom tih elemenata oblikuju se doshe kao karakteristike tijela, uma i svijesti, koje se manifestiraju u fizičko tijelo čime čine određenu tjelesnu konstituciju (prakriti) s dominantnom jednom doshom, dvije (dvodoshna konstitucija) ili tri (trodoshna konstitucija) doshe (Vasant, 1984) s pojedinim tjelesnim i umnim karakteristikama. Vata doshu čine zrak i eter, pitta doshu čine vatra i voda, a kapha doshu čine zemlja i voda.

Primjerice, karakteristike osobe s vata konstitucijom (dominantna vata dosha) jesu sitna tjelesna građa, izrazito velika ili mala tjelesna visina, rijetka kosa (kovrčava i rijetka), tanke trepavice itd. Karakterizira ih hladna, suha i ispucala koža. Fiziološki, apetit i probava su im promjenjivi. Oni su kreativni, aktivni i nemirni. Govore i hodaju brzo, ali se lako umaraju. Osobe pitta konstitucije srednje su tjelesne visine i vitki, jače razvijenih prsa u odnosu na vatu. Kosa im je tanka, crvena ili smeđa, a koža meka, topla i manje hrapava u odnosu na vatu. Prema fiziološkim osobinama, ti su ljudi snažnog i brzog metabolizma. Oni su uglavnom ambiciozni, visoke inteligencije i oštroumni. Osobe kapha konstitucije tjelesno su razvijeni i skloniji debljanju, u odnosu na prethodne dvije konstitucije. Kosa im je debela, tamna, meka i valovita, a koža meka, sjajna i masna. Njihova je probava spora. Krase ih osobine izdržljivosti i snage (Vasant, 1984). Kombinacija navedenih, i dodatnih karakteristika čine dvodoshne i trodoshne tjelesne konstitucije (Vasant, 1984). To su, osim spomenute vate, pitte i kaphe, još i vata - pitta, vata - kapha, pitta - kapha i vata - pitta - kapha (Petrušić, 2015). Eksperimentalnom analizom pojma prakriti (tjelesna konstitucija) dobivena je statistički značajna korelacija između prakriti pojedinca i ekspresije specifičnih gena i biokemijskih parametara (Prasher i sur., 2008).

Načini određivanja tjelesne konstitucije jesu puls dijagnoza, nakon toga pregled urina, stolice, jezika, oči, glave, dodira i općeg tjelesnog statusa što se radi od strane ayurvedskih liječnika dok vlastitu tjelesnu konstituciju možemo procijeniti rješavanjem testa za doshe (Vasant, 1984). Vikriti se definira kao trenutačno stanje tijela koje bi trebalo u što većoj mjeri odražavati prakriti, a ako je stanje daleko od praktriti onda se vikriti može definirati kao narušeno. Manifestira se na fizičkoj, tjelesnoj i psihičkoj razini (Dorland, 2011). U idealnim uvjetima konstitucija bi trebala ostati nepromijenjena, odnosno njezino bi prirođeno stanje trebalo biti u ravnoteži. Međutim, na nju utječe neprestana interakcija s okolinom. Što se više trenutno stanje razlikuje od urođenog, to je pojedinac više u neravnoteži ili bolesti (Petrušić, 2015). Ayurveda uči kako se vikriti može promijeniti načinom života i prehranom da bi se ponovno postigla ravnoteža urođene prakriti, odnosno zdravlje (Petrušić, 2015). Nutricionizam, kao relativno mlada znanost koja, u odnosu na ayurvedu, postoji nešto više od 150 godina, razvila se također kako bi se prehranom unaprijedilo zdravlje i spriječilo bolesti te spriječilo bolesti manjka esencijalnih nutrijenata i osigurao pravilan rast i razvoj. Ayurveda i suvremena znanost o prehrani dijele brojne stavove, primjerice, da ista hrana ne djeluje jednako na sve ljude tj. da je nužna, ali istovremeno vrlo zahtjevna za provedbu tzv. personalizirana prehrana. Također da postoje razlike u preferenciji za određenom hranom, kao i za kvantitativnom potrebom, ali i razlike obzirom na spol ili dob pojedinca te osobine ličnosti i brojne druge odrednice (Rastogi, 2014).

Međutim, pristup je u ayurvedi drugačiji, utoliko što su kod planiranja prehrane primarni okusi. Naime, ona raspoznaje šest okusa s prevlasti dva elementa u hrani (Tripathi, 1994) (slika 1). Osim okusa, ayurveda hrani i doshama pridaje i određene kvalitete i svojstva, opisana također u gore navedenoj knjizi, autora Lada Vasanta (Vasant, 1984).

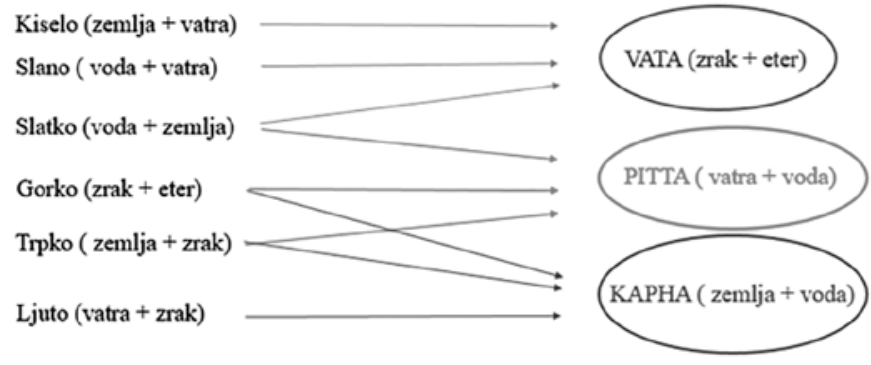

Slika 1. Prikaz okusa koje pogoduju ravnoteži odgovarajuće doshe

Figure 1. Six tastes that favor the right dose balance

Kako bi se održala ravnoteža urođene tjelesne konstitucije, neovisno o vanjskim čimbenicima, pojedinci trebaju unositi određene namirnice, odgovarajućeg okusa, svostva i kvalitete, prema ayurvedi. Hrana koja posjeduje kvalitete slične doshi ili se sastoji od istih elemenata kao i dosha, povećat će tu doshu (odnosno narušiti ravnotežu) dok hrana građena od elemenata koji se razlikuju od doshe, umanjuje ili smiruje doshu, čime ju održava u ravnoteži (slika 1). Primjerice, vata doshom dominiraju zrak i eter (Vasant, 1984). Za ublažavanje elemenata zraka i etera koji određuju vatu, prednost imaju namirnice koje sadržavaju nedostajuće elemente; zemlju, vatru i vodu (Frühmann i Frühmann, 2006). Slano (voda/vatra) je najvažnije za reguliranje vata doshe u tijelu zato jer je teško, masno i zagrijavajuće te poboljšava probavu. Za njim slijedi kiselo (zemlja/vatra) pa slatko (voda/zemlja) (Svoboda, 1999). Pittom dominiraju vatra i voda (Vasant, 1984). Za vraćanje pitte u ravnotežu potrebno je unijeti namirnice s elementima zraka, etera i zemlje. Gorak (zrak/eter) okus je najvažniji za reguliranje pitta doshe jer rashlađuje i suši. Za njim slijedi slatki (voda/zemlja) i trpki (zrak/zemlja) okus (Svoboda, 1999). Kaphom dominiraju zemlja i voda (Vasant, 1984). Elementi vode i zemlje koji obilježavaju kaphu ublažavaju se elementima vatre, zraka i etera (Frühmann i Frühmann, 2006). Ljuti okus (vatra/zrak) primarno djeluje na ublažavanje kaphe jer je zagrijavajuće, lagano i suho. Za njim slijede gorak (zrak/ eter) i trpki (zrak/zemlja) okus (Svoboda, 1999).

Primjerice, na vata doshu povoljno djeluju kuhano povrće, cikla, piletina, banane, naranče, limun, dok nepovoljno utječu heljda, kukuruz, krumpir, sušeno voće. Na pitta doshu umirujuće djeluju naranče, kruške, brokule, celer, gljive, puretina, piletina, zečetina, dok ju banane, šljive, češnjak, cikla, janjetina, svinjetina izbacuju iz ravnoteže. Namirnice poput jabuka, brokule, celera, cvjetače, kukuruza, ječma 
uravnotežuju kaphu, dok ju uneravnotežuju smeđa riža, kuhana zob, krastavci, rajčice, batat te grejp, limun, šljive itd. (Vasant, 1984). Na osnovu ove filozofije za održavanje zdravlja veoma je važno planiranje životnog stila i različitih aktivnosti suprotnim vladajućoj doshi (Purvya i Meena, 2011). Nije nepoznato kako i znanost o prehrani navodi važnost unosa tekućine, provođenja tjelesne aktivnosti, dostatne količine sna i nepušenje kao faktore koji utječu na zdravlje (Golem i sur., 2014).

Kada su ljudi uravnoteženih tjelesnih konstitucija, odnosno zdravi, imaju poriv za gore navedenim okusima. Jako je važno naglasiti da je osnovna pretpostavka ayurvede kako određenu doshu uravnotežuje okus, svojstvo ili navika suprotna njenoj.

Cilj ovog istraživanja bio je ispitati korelaciju prehrambenih navika te konzumacije određenih namirnica, prema principima ayurvede i prakriti, promatrajući ravnotežu pojedinih dosha u tijelu. Sličnih istraživanja u literaturi nedostaje i upravo se potiče provjera ayurvedskih principa različitim važećim dijetetičkim metodama (Rastogi, 2014).

\section{Ispitanici i metode}

\section{Upitnik za određivanje tjelesne konstitucije}

Za određivanje tjelesne konstitucije korišten je upitnik, nastao modificiranjem uvriježenog upitnika za određivanje tjelesne konstitucije (Bilić, 2008).

Upitnik sadržava tri kategorije za svaku doshu od po 25 tvrdnji, dakle ukupno 75. Tvrdnje se odnose na fiziološke, psihološke i anatomske aspekte, a odgovori su ponuđeni u obliku skale od 1 do 6, gdje 1 znači „,ne odgovaraju meni“, a 6 „najviše mi odgovaraju“. Stoga je ukupan makisimalni zbroj bodova pod pojedinom kategorijom 150 (6*25), a minimalni $25(1 * 25)$.

Osobi se dodijeljuje svojstvo specifične tjelesne konstitucije ovisno o postignutim rezultatima. Najveći broj bodova ostvaren za određenu doshu u odnosu na druge dvije kategorije dosha označava tu tjelesnu konstituciju. Npr. osoba je pitta tjelesne konstitucije ukoliko rezultati upitnika izgledaju ovako: vata 80 bodova, pitta 130, kapha 60 .

Ukoliko se bodovi između dvije kategorije dosha razlikuju za 10 bodova, radi se o dvodoshnoj konstituciji, a razlika od 5 bodova između sve tri kategorije čini trodoshnu konstituciju. Upitnik se ispunjava dva puta. Prvi put prema tome kako se pojedinac osjeća veći dio života, čime dobivamo podatak o tjelesnoj konstituciji (u daljnjem tekstu KONSTITUCIJA 1) (prakriti), a drugi put za trenutno stanje gdje dobivamo podatak o postojanju narušenosti tjelesne konstitucije (KONSTITUCIJA 2) (vikriti). Narušena tjelesna konstitucija se definira kao povišen broj bodova pod kategorijom doshe (minimalno 10 bodova) u odnosu na istu kategoriju u prvom testu. Ukoliko se broj bodova za sve tri kategorije između dva upitnika ne razlikuje, nije došlo do poremećaja te je pojedinac u ravnoteži. Dakle, moguće je dobiti 7 uravnoteženih te 7 narušenih tjelesnih konstitucija (navedenih u uvodu).

\section{Dijetetičke metode}

\section{Upitnik o prehrambenim navikama}

Upitnikom o prehrambenim navikama (u daljnjem tekstu PREHRANA 1) cilj je bio utvrditi usklađenost načina prehrane prema ayurvedi. Upitnik sadržava 32 tvrdnje. Tvrdnje su raspoređene u 3 kategorije po 10 pitanja (za svaku doshu) te dodatna 2 vezana za učestalost pušenja. Tvrdnje se boduju s 1 , 0,5 i 0 bodova, te je maksimalni broj bodova pod određenom kategorijom 12. Veći broj bodova u određenoj kategoriji označava prehranu koja uravnotežuje tu doshu, dok manji broj bodova označava prehranu koja uneravnotežuje tu doshu. Upitnik je sastavljen na temelju preporučenih prehrambenih navika za svaku doshu (Frühmann i Frühmann, 2006). Tvrdnje se odnose na pristup jelu, učestalost jedenja, unošenje tekućine, konzumiranje slastica ili alkohola te pušenje.

U upitniku, kod tvrdnje o učestalosti konzumiranja doručka, pod kategorijom vata, odgovor rijetko (1-2x/tjedan) nosi 0 bodova, često (3-5x/tjedan) 0,5 bodova, a svaki dan 1 bod. Pod kategorijom pitta bodovanje je isto kao i kod vate, a pod kategorijom kaphe odgovor rijetko (1-2x/tjedan) nosi 1 bod, često (3-5x/tjedan) 0,5 bodova, a svaki dan 0 bodova.

\section{Upitnik o učestalosti konzumiranja hrane}

Cilj upitnika o učestalosti konzumiranja hrane (u daljnjem tekstu PREHRANA 2) bio je odrediti usklađenost konzumiranja namirnica prema ayurvedi. Sastoji se od popisa 72 namirnice, svrstane u skupine: povrće, voće, žitarice, mahunarke, mliječni proizvodi, sjemenke i začini, zaslađivači, orašasto voće, ulja i meso (Vasant, 1984; Kušer-Mijić, 2013).

Upitnik ispituje učestalost konzumiranja, a mogući odabir odgovora jesu „rijetko“ ili „,̌esto“. Tvrdnje se boduju s 1 i 0 . Bodovi se pridodaju ovisno o kategorijama doshe određene upitnikom za određivanje tjelesne konstitucije.

Namirnice su svrstane prema doshama, što znači da sadrže element i kvalitetu jednaku toj doshi. Te su namirnice nepogodne za tu doshu, odnosno toj doshi odgovaraju one namirnice sa suprotnim kvalitetama.

Ukoliko namirnica uravnotežuje doshu odgovor „često“ nosi 1 bod, a odgovor „rijetko“ 0 bodova pod kategorijom za tu doshu, a kod namirnice koja izbacuje doshu iz ravnoteže, bodovanje je suprotno. Primjerice, za tikvicu, odgovor ,rijetko" nosi 1 bod pod kategorijom kapha, dok se isti odgovor za vata i pitta doshu boduje suprotno (tj. dodjeljuje se 0 bodova).

Veći broj bodova pod određenom kategorijom doshe označava prehranu sukladnu toj doshi. Što je zbroj bodova u određenoj kategoriji doshe manji, prehrana nije u sukladnosti s tom doshom.

\section{Ispitanici}

Istraživanje o utjecaju prehrane na ljudski organizam prema postulatima ayurvede, uzimajući u obzir konstitucijske tipove provedeno je među odraslom populacijom ( $n=210,129$ žena i 81 muškaraca) u Republici Hrvatskoj u periodu siječanj-ožujak 2017. godine. Svi ispitanici su omnivore (svejedi), zdravi, adekvatne tjelesne mase (BMI: 18,5-25), bez kroničnih oboljenja i konzumiranja lijekova. Ispitanici za ovo istraživa- 
nje izabrani su putem društvenih mreža, a testove su ispunjavali „online“".

Ispitanici su podijeljeni u 7 skupina prema njihovoj tjelesnoj konstituciji, te 7 skupina neravnoteže.

\section{Statistička analiza}

Statistička analiza izvršena je u programskom paketu MS Excell 2013. U svim statističkim analizama, pri potvrdi početne hipoteze, rezultati su bili statistički značajni ako je $\mathrm{p}<0,1$.

Pearsonov koeficijent korelacije izračunat je između tjelesne konstitucije (udio dominantne doshe u zbroju svih dosha) definirane prema ayurvedi i konzumiranih namirnica (rezultat bodova pod kategorijom te doshe), te između tjelesne konstitucije i prehrambenih navika. Kod uneravnoteženih tjelesnih konstitucija, izračunat je Pearsonov koeficijent korelacije između uneravnotežene tjelesne konstitucije (razlika udjela dosha u zbroju svih dosha za prvi upitnik riješen prvi put i prvi upitnik riješen drugi put) i konzumiranih namirnica (rezultat bodova pod kategorijom te doshe), te između neravnoteže i prehrambenih navika.

Izračunat je i Pearsonov koeficijent korelacije između svih jednodoshnih poremećaja neovisno o početnoj tjelesnoj konstituciji (razlika udjela povišenih dosha u zbroju svih dosha za prvi upitnik riješen prvi put i prvi upitnik riješen drugi put) i podataka o prehrambenim navikama (rezultat bodova pod kategorijom doshe), a u drugom koraku jednodoshni poremećaji s konzumiranim namirnicama.

\section{Rezultati i rasprava}

Ayurveda je drevna znanost Indijske medicine, jedna od najraširenijih među komplementarnom i alternativnom medicinom (WHO, 2010), prakticirana više od 5000 godina i prvi je put opisana u Charak Samhiti, gdje su dane više od 1500 biljaka i 10000 biljnih pripravaka koji se koriste u liječenju različitih bolesti (Sharma, 2001). Iako je malo istraživanja koja uspoređuju i povezuju ayurvedu sa zapadnom medicinom, psihologijom i znanosti o prehrani, objavljeni radovi o ayurvedskoj medicini ukazuju na znanstvenu osnovu ayurvedskog liječenja različitih bolesti (Agarwal i sur., 2010; Sehgal i sur., 2012; Chopra i sur., 2013). Također, drevni sustav ayurvede pruža bazu znanja koja se može koristiti za razvoj novih terapijskih strategija (Patwardhan i Mashelkar, 2009). Brojna su istraživanja koja navode pozitivne rezultate u liječenju ayurvedom, primjerice u liječenju raka (Surh i sur., 2001), astme (Joshi i sur., 2015), oboljelih od dijabetesa tipa 2 (William i sur., 1993) (Baskaran i sur., 1990) (Khare i sur., 1983) i tipa 1 (Shanmugasundaram i sur., 1990). Ayurveda uobičajeno pacijentima s dijabetesom propisuje smanjenje unosa ili čak izbjegavanje slatke i teške hrane. Osim toga, savjetuje i konzumiranje gorkog, trpkog i kiselog okusa, kao i dodavanje određenog voća, povrća i začina u prehranu, kao što su gorka tikva, šparoge, špinat, kurkuma, sjeme piskavice, crni papr, i đumbir (Eldeer, 2004). Također, biljni lijekovi imaju pozitivni učinak $\mathrm{u}$ tretiranju pacijenata $\mathrm{s}$ iritabilnim sindromom crijeva - IBS (engl. Irritable bowel syndrome) (Liu i sur., 2006) (Kapoor, 2014). Obzirom da je u ayurvedi prehrana najbolji lijek (Cha- van i sur., 2016), za sindrom iritabilnog crijeva preporučuje se izbjegavanje nadražujuće hrane poput kofeina, gaziranih napitaka te jednostavnih ugljkohidrata (Torpy i Golub, 2011) čije izbjegavanje pokazuju izvrsne rezultate u smanjenju nadutosti (Heizer i sur., 2009). Dokazano je također kako yoga, kao jedan od pristupa u ayurvedi umanjuje gastrointestinalne simptome i normalizira simpatički ton u pacijenta sa IBS (Grundmann i Yoon, 2014).

Analizom rezultata upitnika KONSTITUCIJA 1 i 2 određeno je sedam mogućih tjelesnih konstitucija, odnosno neravnoteža istih, a to su: vata, pitta, kapha, vata-pitta, pitta-kapha, vata-kapha te vata-pitta-kapha. Dobiveno je 154 (73\%) jednodoshnih tjelesnih konstitucija, odnosno 8 vata, 113 pitta i 33 kapha tjelesnih konstitucija što predstavlja 3,81\%, 53,81\% te $15,71 \%$ uzoraka (tablica 2). Dvodoshnih tjelesnih konstitucija u ovom je istraživanju dobiveno 54 (25,74 \%), od kojih je 14 vata-pitta konstitucije, 39 pitta-kapha te 1 vata-kapha konstitucija koji predstavljaju $6,67 \%, 18,57 \%$ te $0,48 \%$ uzoraka (tablica 2). Samo su dvije osobe vata-pitta-kapha tjelesne konstitucije.



Slika 2. Usporedba dobivenih jednodosnih tjelesnih konstitucija u ovom istraživanju i Della Fave sa suradnicima (Della Fave i sur., 2014)

Figure 2. The comparisons of one dosha body constitutions in this research of Della Fave et al (Della Fave et al., 2014)

Iako je poznato kako su dvodoshni tipovi daleko češći od jednodoshnih tipova (Srikantha Murty, 2007), u istraživanju (Della Fave i sur., 2014) koje je promatralo povezanost tjelesne konstitucije (definirane prema ayurvedi), osobnost $i$ emocionalne karakteristike (prema zapadnoj psihologiji), zamijećena je neravnoteža obzirom na zastupljenost pitta tjelesne konstitucije (slika 2). Naime, od ukupno 391 ispitanika koje je sudjelovalo u istraživanju u Italiji, njih čak 87 bilo je pitta tjelesne konstitucije, dok je u ovom istražianju bilo njih 113, od ukupno 210 ispitanika. Istraživanje koje su proveli Rotti i sur. promatrali su tjelesnu konstituciju pojedinca obzirom na mjesto stanovanja. Analiza tjelesne konstitucije provedena je na 3 različite geografske lokacije u Indiji; Bangalore, Pune i Udupi. Na području Pune dobiveni su rezultati pokazali dominaciju vata tjelesne konstitucije $(58,8 \%)$, dok je na podružju Udupi dominirala kapha tjelesna konstitucija (57,6\%) (slika 3). Za razumijevanje razlike u raspodjeli tjelesnih konstitucija, ispitali su utjecaj geografskih područja; mjesta rođenja dominantnih 
tjelesnih konstitucija pojedinaca (Rotti i sur., 2014). U ayurvedskim tekstovima naznačeno je da se pet elemenata (zrak, zemlja, eter, vatra i voda) kombiniraju u različitim omjerima u zemlji, flori, životinjama, ali i ljudima (Archarya, 1997). Svako geografsko područje će imati jedan ili drugi element koji dominira u njemu te prirodni afinitet prema odgovarajućoj doshi, a time i odgovarajućoj tjelesnoj konstituciji. Pa su tako, primjerice voda i kapha dosha dominantne u mokrim zemljama. Tako da će mokra zemlja pokazati visoku učestalost kapha tjelesne konstitucije. Geografsko područje Pune po prirodi je suho te je sukladno tome dominatno s populacijom vata tjelesne konstitucije, dok je Udupi mokro područje, dominantno s populacijom kapha tjelesne konstitucije (Rotti i sur., 2014).

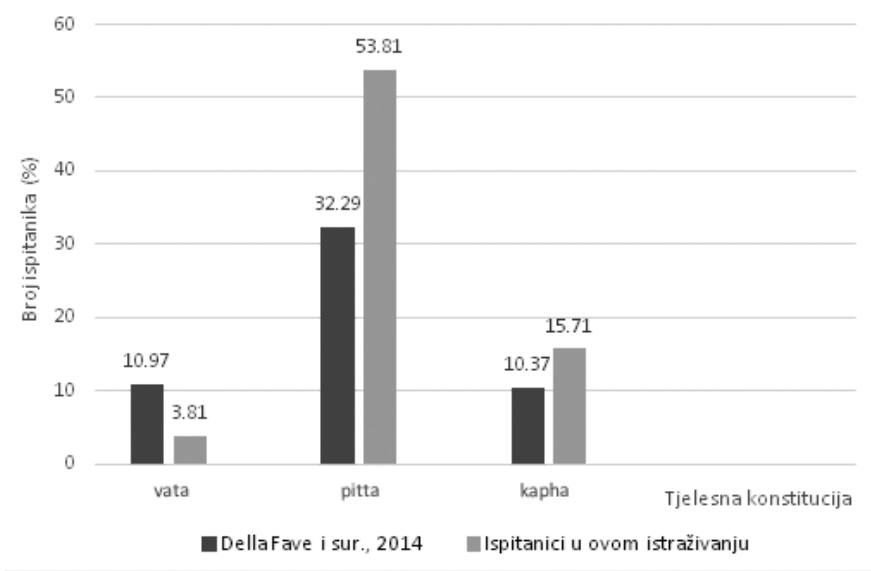

Slika 3. Raspodjela tri tjelesne konstitucije u tri geografska područje Indije (Rotti i sur., 2014)

Figure 3. Distribution of three body constitution in three different geographical areas of India
Sukladno tome, od ukupnog broja ispitanika (3416), dobili su čak $41 \%$ vata i kapha ispitanika, a samo $18 \%$ pitta ispitanika, što je u nesrazmjeru s ovim i Della Fave i sur. istraživanju. Trebalo bi napraviti analizu geografskog područja Italije i Hrvatske gdje su provedena istraživanja radi utvrđivanja zastupljenosti tjelesnih konstitucija. Od ukupnog broja ispitanika, $131(62,38 \%)$ imaju uravnoteženu tjelesnu konstituciju, dok njih 79 (37,62 \%) ima uneravnoteženu (tablica 3). Među uravnoteženim tjelesnim konstitucijama $(\mathrm{n}=131)$, ali i među neravnoteženim $(\mathrm{n}=79)$ ističu se pitta tjelesne konstitucije, $\mathrm{n}=75(57,25 \%)$, odnosno pitta $\mathrm{n}=38(48,10 \%)$ (tablica 3$)$. Od ukupnih stanja neravnoteže čak 38 njih svrstano je u kategoriju poremećaja vate $(48,1 \%)$. Najveću zastupljenost poremećaja vate $(48,1 \%)$ potvrđuje podatak da je danas bez obzira na konstituciju, poremećaj vate najčešći (Petrušić, 2015). Također zimski period kada je provedeno ovo istraživanje (siječanjožujak) dodatno uneravnotežuje vata doshu (Thakkar i sur., 2011).

Tablica 2. Prikaz broja ispitanika raspoređenih prema tjelesnoj konstituciji

Table 2. Number of subjects deployed according to the body constitution

\begin{tabular}{|l|c|c|}
\hline Tjelesna konstitucija & $\begin{array}{c}\text { Broj ispitanika } \\
\text { (n) }\end{array}$ & Postotak (\%) \\
\hline Vata & 8 & 3,81 \\
\hline Pitta & 113 & 53,81 \\
\hline Kapha & 33 & 15,71 \\
\hline Vata - Pitta & 14 & 6,67 \\
\hline Pitta - Kapha & 39 & 18,57 \\
\hline Vata - Kapha & 1 & 0,48 \\
\hline Vata - Pitta - Kapha & 2 & 0,95 \\
\hline
\end{tabular}

Tablica 3. Raspodjela broja ispitanika prema ravnoteži i neravnoteži

Table 3. Number of subjects deployed by balance and imbalance

\begin{tabular}{|l|l|l|l|}
\hline Uravnotežene tjelesne konstitucije & Broj $(\mathrm{n} ; \%)$ & Uneravnotežene tjelesne konstitucije & Broj (n; \%) \\
\hline Vata & $3 ; 3,29 \%$ & Vata & $5 ; 6,33 \%$ \\
\hline Pitta & $75 ; 57,25 \%$ & Pitta $\%$ & $38 ; 48,10 \%$ \\
\hline Kapha & $17 ; 12,98 \%$ & Kapha & $16 ; 20,25 \%$ \\
\hline Vata - Pitta & $5 ; 3,81 \%$ & Vata - Pitta & $9 ; 11,39 \%$ \\
\hline Pitta - Kapha & $30 ; 22,9 \%$ & Pitta - Kapha & $9 ; 11,39 \%$ \\
\hline Vata - Kapha & $1 ; 0,76 \%$ & Vata - Kapha & $-;-$ \\
\hline Vata - Pitta - Kapha & $-;-$ & Vata - Pitta - Kapha & $2 ; 2,53 \%$ \\
\hline Ukupno & $131 ; 100 \%$ & Ukupno & $79 ; 100 \%$ \\
\hline
\end{tabular}

Ayurveda navodi da prehrambene navike, cjelokupna prehrana i životni stil usklađeni s dominantnom doshom dovode do ravnoteže te doshe, dok neusklađenost povisuje tu doshu i uneravnotežuju je (Svoboda, 1999).

Unutar ovog istraživanja prvo je ispitivana korelacija između rezultata upitnika KONSTITUCIJA 1 i rezultata upitnika PREHRANA 1, čime je dobivena pozitivna korelacija samo za kapha tjelesnu konstituciju, što potvrđuje povezanost tjelesne konstitucije kapha i njenih prehrambenih navika. Za druge dvije tjelesne konstitucije, povezanost nije uočena. Korelacija između rezultata upitnika KONSTITUCIJA 1 i rezultata upitnika PREHRANA 2 nije uočena. Drugim riječima, nema povezanosti između uravnoteženih tjelesnih konstitucija i njihove prehrane (tablica 4). 
Tablica 4. Prikaz korelacije rezultata KONSTITUCIJA $1 i$ rezultata upitnika PREHRANA 1, te upitnika PREHRANA 2

Table 4. Correlation between the results of CONSTITUTION 1 and the results of DIET 1 and DIET 2 questionnaires

\begin{tabular}{|l|l|l|}
\hline $\begin{array}{l}\text { Tjelesna kon- } \\
\text { stitucija u } \\
\text { ravnoteži }\end{array}$ & $\begin{array}{l}\text { Rezultati upitnika } \\
\text { PREHRANA 1 (r) }\end{array}$ & $\begin{array}{l}\text { Rezultati upitnika } \\
\text { PREHRANA 2 (r) }\end{array}$ \\
\hline Vata & -1 & -1 \\
\hline Pitta & $-0,21$ & $-0,14$ \\
\hline Kapha & 0,29 & $-0,16$ \\
\hline
\end{tabular}

U slijedećem koraku, u korelaciju su stavljeni rezultati upitnika KONSTITUCIJA 2 (podaci o neravnoteži) i rezultati upitnika PREHRANA 1. Rezultati ukazuju samo na povezanost pitta neravnoteže i prehrambenih navika za pitta neravnotežu, dok kod vata i kapha neravnoteže povezanost nije utvđena. Izračun korelacije proveden je i za rezultate upitnika KONSTITUCIJA 2 i PREHRANA 2. Rezultati su potvrdili povezanost između vata i kapha neravnoteže i konzumiranih namirnica koji podržavaju neravnotežu, dok za pitta tjelesnu konstituciju nije uočena korelacija (tablica 5).

Tablica 5. Prikaz koeficijenta korelacije između rezultata KONSTITUCIJA 2 (neravnoteža) i rezultata PREHRANA 1 i PREHRANA 2

Table 5. Correlation between the results of CONSTITUTION 2 (imbalance) and the results of DIET 1 and DIET 2 questionnaires

\begin{tabular}{|l|l|l|}
\hline $\begin{array}{l}\text { Vrsta neravnoteže } \\
\text { tjelesnih kon- } \\
\text { stitucija }\end{array}$ & $\begin{array}{l}\text { Rezultati upitnika } \\
\text { PEHRANA 1 }\end{array}$ & $\begin{array}{l}\text { Rezultati upitnika } \\
\text { PREHRANA 2 }\end{array}$ \\
\hline Vata poremećaj (r) & 0,16 & $-0,18$ \\
\hline Pitta poremećaj (r) & $-0,62$ & 0,21 \\
\hline $\begin{array}{l}\text { Kapha poremećaj } \\
\text { (r) }\end{array}$ & 0,1 & $-0,43$ \\
\hline
\end{tabular}

\section{Zaključci}

U istraživanju čiji je cilj bio utvrditi usklađenost tjelesne konstitucije (prakriti) i prehrane prema ayurvedskim principima može se zaključiti da iako su ispitanici u ovom istraživanju zdravi (adekvatne tjelesne mase, bez kroničnih oboljenja i konzumiranja lijekova), prema ayurvedi njih 79 (37,62 \%) je u neravnoteži, te iako se ta neravnoteža nije manifestirala na tijelu upućuje na potrebu za promjenom prehrane.

Zbog činjenice da ispitanici nisu pokazali očekivane prehrambene navike potrebno je potvrditi utvrđenu korelaciju korištenjem puls dijagnoze kao i druge dijetetičke metode, primjerice dnevnikom prehrane kako bi se mogli uzeti u obzir i drugi čimbenici koje ayurveda kao holistička znanost uključuje u svojoj praksi.

\section{Literatura}

Acharya J. T. (1997) Sushrutha samhita, Sutra Sthana 35/42, Varanasi: Chaukhambha Sanskrit Sansthan, str. 157158.

Acharya J. T. (2002) The Charakasamhita of Agnivesa with the Ayurveda dipika commentary by Chakrapanidatta, 5.izd., Varanasi: Chaukhambha Orientalia.

Acharya J. T. (2002) Sushruta Samhita, 7.izd., Varanasi: Chaukhambha Orientalia.

Agarwal S., Negi S., Jha P., Singh P., Stobdan T., Qadar Pasha M. A., Ghosh S., Agrawal A. (2010) Indian genome variation consortium. EGLN1 involvement in high altitude adaptation revealed through genetic analysis of extreme constitution types defined in Ayurveda. Proceedings of the National Academy of Sciences of the United States of America 107 18961-18966.

Barnett J. E., Shale A. J. (2012) The integration of Complementary and Alternative Medicine (CAM) Into the Practice of Psychology: A Vision for the Future. Professional Psychology Research and Practice, 43 576-585.

Baskaran K., Kizar A. B., Radha S. K., Shanmugasundaram E. R. (1990) Antidiabetic effect of a leaf extract from Gymnema sylvestre in non-insulin-dependent diabetes mellitus patients. Journal of Ethnopharmacology, 3 295-300.

Bilić D. (2008) Danvantari ayurveda,1.izd., Neron, Bjelovar, str. 38.

Chaudhary A., Singh N. (2011) Contribution of world health organization in the global acceptance of Ayurveda. Journal of Ayurveda and Integrative Medicine, 2 179-186.

Chavan S. V., Sambare S. S., Joshi A. (2016) Diet recommendation on prakriti and season using fuzzy ontology and type -2 fuzzy logic. 2016 International Conference on Computing Communication Control and Automation (ICCUBEA) doi: 1.1109/iccubea.2016.7860026.

Chopra A., Saluja M., Tillu G., Sarmukkaddam S., Venugopalan A., Narsimulu G., Handa R., Sumantran V., Raut A., Bichile L., Joshi K., Patwardhan B. (2013) Ayurvedic medicine offers a good alternative to glucosamine and celecoxib in the treatment of symptomatic knee osteoarthritis: a randomized, double-blind, controlled equivalence drug trial. Rheumatology, 152 1408-1417.

Collins H. (2011) Collins English Dictionary, 11.izd., Harper Collins Publishers Ltd.

Cordain L., Eaton S. B., Sebastian A., Mann N., Lindeberg S., Watkins B. A. (2005) Origins and evolution of the Western diet: health implications for the 21 st century. The American Journal of Clinical Nutrition, 81 341-354.

Della Fave A., Negri L., Manohar Ram P., Morandi A., Bassi M. (2014) The ayurveda concept of prakriti and the western construct of personality: A comparative pilot study. European Journal of Integrative Medicine, 360 1-13.

Eldeer C. (2004) Ayurveda for diabetes mellitus: a review of the biomedical literature. Alternative Therapies in Health and Medicine, 10 44-50.

Frühmann E., Frühmann W. (2006) Ayurveda - Indijski put do harmonije, 1.izd., Kneippova zdravstvena biblioteka, Večernjakova knjiga, Zagreb.

Golem D. L., Martin-Biggers J. T., Koenings M. M., Davis K. F., Byrd-Bredbenner C. (2014) An integrative review 
of sleep for nutrition professionals. Advances in Nutrition, 5 742-759.

Grundmann O., Yoon S. L. (2014) Complementary and alternative medicine for treatment of irritable bowel syndrome. The College of Family Physicians of Canada, 55 143-148.

Heizer W. D., Southern S., McGovern S.. (2009) The role of diet in symptoms of irritable bowel syndrome in adults: a narrative review. Journal of the American Dietetic Association, 109 1204-1214.

Hussain Z., Quigley E. M. M. (2006) Systematic review: complementary and alternative medicinein the irritable bowel syndrome. Alimentary Pharmacology and Therapeutics, 23 465-471.

Joshi K. S., Nesari T. M., Dedge A. P., Dhumal V. R., Shengule S. A., Gadgil M. S., Salvi S., Sankaran Valiathan M. V. (2015) Dosha phenotype specific Ayurveda intervention ameliorates asthma symptoms through cytokine modulations: Results of whole system clinical trial. Journal of Ethnopharmacology, 197 110-117.

Kapoor A. B. (2014) Study on clinical efficacy of sanjivani vati and Lashunadi vati in management of diarrhea predominant IBS: a pilot study. Journal of Ayurveda and Integrative Medicine, 2 13-22.

Khare A. K., Tondon R. N., Tewari J. P. (1983) Hypoglycaemic activity of an indigenous drug (Gymnema sylvestre, Gumar) in normal and diabetic persons. Indian Journal of Physiology and Pharmacology, 3 257-258.

Kušer-Mijić S. (2013) Kuhinja zdravlja, 1.izd., Vlastita naklada, Zagreb.

Liu J., Yang M., Liu Y. (2006) Herbal medicines for treatment of irritable bowel syndrome. The Cochrane Database of Systematic Reviews, 25.

Patwardhan B., Mashelkar R. A. (2009) Traditional medicine-inspired approaches to drug discovery: can Ayurveda show the way forward? Drug Discovery Today, 14 804-811.

Petrušić T. (2015) Ayurveda nauk o životu, 2.izd., Harša, Bregana.

Prasher B., Aggarwal A.K., Mandal Sethi T. P., Deshmukh S. R., Purohit S. G., Sengupta S., Khanna S., Mohammad F., Garg G., Brahmachari S. K., Indian Genome Variation Consortium, Mukerji M. (2008) Whole genome expression and biochemical correlates of extreme constitutional types defined in Ayurveda. Journal of Translational Medicine, 6 48-60.

Prasher B., Negi S., Aggarwal S., Mandal A. K., Sethi T. P., Deshmukh S. R., Purohit S. G., Sengupta S., Khanna S., Mohammad F., Garg G., Brahmachari S. K. (2008) Whole genome expression and biochemical correlates of extreme constitutional types defined in Ayurveda. Journal of Translational Medicine, 648.

Purvya M. C., Meena M. S. (2011) A review of role of prakriti in aging. Ayu, 32 20-24.

Rastogi S. (2010) Building bridges between Ayurveda and modern science. International Journal of Ayurveda Research, 1 41-46.

Rastogi S. (2014) Ayurvedic Principles of Food and Nutrition: Translating Theory into Evidence-Based Practice. U: Ayurvedic Science of Food and Nutrition, (Rastogi, S., ured.), Springer New York Heidelberg Dordrecht London, str. 4,5.

Rastogi S. (2014) From Book to Bedside: Challenges of Translating Ayurvedic Science of Food and Nutrition for the
Common Benefits. U: Ayurvedic Science of Food and Nutrition, (Rastogi, S., ured.), Springer New York Heidelberg Dordrecht London, str.162,163.

Rotti H., Raval R., Anchan S., Bellampalli R., Bhale S.,Bhardawaj R., Bhat K. B., Dedge P. A., Ram Dhumal V., Gangadharan G. G., Girijakumari T. K., Gopinath M. P., Govindaraj P., Halder S., Joshi S. K., Prasada Kabekkodu S., Kamath A., Kondaiah P., Kureja H., Rajath Kumar K. L., Nair S., Venugopalan Nair S. N., Nayak J., Prasanna B. V., Rashmishree M., Sharanprasad K., Thangaraj K., Patwardhan b., Satyamoorthy K., Sankaran Valiathan M. V. (2014) Determinants of Prakriti, the Human Constitution Types of Indian Traditional Medicine and Its Correlation with Contemporary Science. Journal of Ayurveda and Integrative Medicine, 5 167-175.

Sehgal N, Gupta A., Khader Valli R., Joshi S. D. D., Mills J. T., Hamel E., Khanna P., Jain S. C., Thakur S. S., Ravindranath V. (2012) Withaniasomnifera reverses alzheimer's diseasepathology by enhancing low-density lipoprotein receptorrelated protein in liver. Proceedings of the National Academy of Sciences of the Unated States of America, 109 3510-3515.

Sharma H., Clark C. (1997) Contemporary Ayurveda: Medicine and Research in Maharish Ayurveda, 1.izd., New York: Churchill Livingstone Publisher (Elsevier),. New York.

Sharma R.K, Dash B. (2001) Agnivesa's Charaka Samhita. Text with English Translation \& Critical Exposition Based on Cakrapani Datta's Ayurveda Dipika, 2.izd., Chowkhamba Sanaskrit Series Office, Varanasi: Chowkhamba Sanaskrit Series Office.

Surh Y. J., Chun K. S., Cha H. H., Han S.S., Keum Y. S., Park K. K., Lee S. S. (2001) Molecular mechanisms underlying chemopreventive activities of anti-inflammatory phytochemicals: down-regulation of COX-2 and iNOS through suppression of NF- $\mathrm{BB}$ activation. Mutation Researches, 480-481 243-268.

Svoboda E.R. (1999) Your ayurvedic constitution- Prakruti by Robert E.Svoboda. Lotus Press.USA.

Torpy J., Golub R. (2011) Irritable bowel syndrome. Journal of the AMA, 3061501.

Tripathi B. N. (1994) Charaka samhita. Varanasi : Chaukhambha orientalia, Varanasi.

Vasant L. (1984) Ayurveda the science of self healing, Lotus pres. Santa Fe, New Mexico.

WHO (2010) Benchmarks for Training in ayurveda. WHO - World Health Organisation, WHO press, Geneva, Switzerland.

William F., Lakshminarayanan S., Chegu H. (1993) Effect of some indian vegetables on the glucose and insulin response in diabetic subjects. International Journal of Food Sciences and Nutrition, 44 191-195. 